(2) Open Access Full Text Article

\title{
Aggressiveness, violence, homicidality, homicide, and Lyme disease
}

This article was published in the following Dove Press journal:

Neuropsychiatric Disease and Treatment

\section{Rosalie Greenberg}

Medical Arts Psychotherapy

Associates PA, Summit, NJ, USA
Correspondence: Rosalie Greenberg Medical Arts Psychotherapy Associates PA, 33 Overlook Road, Suite 406, Summit, NJ 0790I, USA

$\mathrm{Tel}+\mathrm{I} 9085980200$

Fax + I 9085980924

Email baredeso@aol.com

\section{Dear editor}

I read with great interest the article by Bransfield, ${ }^{1}$ wherein the author reviewed potential contributors to and manifestations of heightened loss of control in Lyme disease patients. As a child psychiatrist living in a Lyme-endemic state, New Jersey, in the USA, I have seen a number of children and adolescents who exhibit significant acute or gradual onset of highly oppositional behaviors often both at home and at school. Refusal to do classwork or homework, heightened paranoia or feeling rejected by others is often present. In addition, they often demonstrate increased irritability, extreme temper tantrums, problems concentrating, elevated impulsivity, sensory hypersensitivity (sound, touch, smell, taste and/or light) and intense emotional lability. Parents describe these behaviors as either a sudden change or a period of worsening of a previous condition, such as attention-deficit hyperactivity disorder or mood disorder. During periods of intense anger over minimal issues, they can appear menacing and threaten to kill a sibling, parent or a friend or state that they want to die themselves. In a recent record review of 69 youth evaluated in my private psychopharmacology practice, 49 of these new patients, without a known history of Lyme disease or other tick-borne disorders, demonstrated evidence of exposure to one or more of the pathogens Borrelia burgdorferi, Bartonella, Babesia, Ehrlichia and Anaplasma on serologic testing performed by multiple laboratories. In addition, 6 of the 69 patients were initially referred because of psychiatric difficulties observed by other physicians during the active treatment of tick-borne infections. Supporting this connection of childhood neuropsychiatric symptoms and tick-borne illness is a recent article looking at 27 youth diagnosed with bipolar disorder I or II, which found that $74 \%$ or $20 / 27$ were diagnosed with at least one tick-borne illness based on serologic testing and clinician evaluation. ${ }^{2}$ Of note, bipolar disorder is a psychiatric illness that carries a high risk of suicide. There appears to be no question that exploration of the association of Lyme disease and tick-borne illnesses with neuropsychiatric symptoms both in children and adults requires more extensive study.

\section{Disclosure}

The author reports no conflicts of interest in this communication.

\section{References}

1. Bransfield RC. Aggressiveness, violence, homicidality, homicide, and Lyme disease. Neuropsychiatr Dis Treat. 2018;14:693-713.

2. Greenberg R. Infections and childhood psychiatric disorders: tick-borne illness and bipolar disorder in youth. Bipolar Disord. 2017;3:113. 


\section{Author's reply}

Robert C Bransfield

Department of Psychiatry, Rutgers-Robert Wood Johnson Medical School, Piscataway, NJ, USA

Correspondence: Robert C Bransfield

Department of Psychiatry, Rutgers-Robert Wood Johnson Medical

School, 675 Hoes Lane West, Piscataway, NJ 08854, USA

$\mathrm{Tel}+\mathrm{I} 73274 \mid 3263$

Fax +I 7327415308

Email bransfield@comcast.net

\section{Dear editor}

Dr Greenberg's letter is highly significant and addresses four key points - it independently collaborates the finding that tick-borne disease causes aggressiveness; with a different study design, it independently collaborates the finding that tick-borne disease causes significant psychiatric symptoms, including childhood bipolar illness; it further expands my findings to address children and adolescents, and it also discusses the role of tick-borne coinfections.

Dr Greenberg collaborated my finding that tick-borne diseases cause aggressiveness by writing she has observed aggressiveness as oppositional behavior, irritability, extreme temper tantrums, elevated impulsivity, intense emotional lability, periods of intense anger, appearing menacing and threatening to kill a sibling, parent or a friend. While my study of patients diagnosed with Lyme disease demonstrated significant psychiatric symptoms evolved postinfection, her study from a different perspective demonstrated $80 \%$ (55 of 69) of identified psychiatric patients tested positive for tick-borne disease suggesting these diseases play a significant role in the pathogenesis of mental illnesses and also childhood bipolar illness (74\%). Dr Greenberg demonstrated her findings in children and adolescents, while my study did not separate the findings seen in adults vs children and adolescents. Her study also expanded to a more thorough assessment of the role of tick-borne coinfections. Ticks are considered cesspools of pathogens and nature's dirty needle. Recent microarray testing of the tick microbiome demonstrated a large number of pathogens, including some that had previously not been recognized. ${ }^{1}$

I am encouraged to see others expanding upon this research. I hope to see greater awareness, further research and changing policies in this area to help prevent violence.

\section{Disclosure}

The author reports no conflicts of interest in this communication.

\section{Reference}

1. Ehrlich GD. Development of pan-domain diagnostics to provide accurate and comprehensive analyses of Lyme disease and tick-borne co-infections. Presented at: ILADS Annual Meeting; November 9, 2017; Boston, MA.

Dove Medical Press encourages responsible, free and frank academic debate. The content of the Neuropsychiatric Disease and Treatment 'letters to the editor' section does not necessarily represent the views of Dove Medical Press, its officers, agents, employees, related entities or the Neuropsychiatric Disease and Treatment editors. While all reasonable steps have been taken to confirm the content of each letter, Dove Medical Press accepts no liability in respect of the content of any letter, nor is it responsible for the content and accuracy of any letter to the editor.

\section{Publish your work in this journal}

Neuropsychiatric Disease and Treatment is an international, peerreviewed journal of clinical therapeutics and pharmacology focusing on concise rapid reporting of clinical or pre-clinical studies on a range of neuropsychiatric and neurological disorders. This journal is indexed on PubMed Central, the 'PsycINFO' database and CAS, and is the official journal of The International Neuropsychiatric Association (INA). The manuscript management system is completely online and includes a very quick and fair peer-review system, which is all easy to use. Visit http://www.dovepress.com/testimonials.php to read real quotes from published authors. 